\title{
KARDIOMIOPATI PADA INFEKSI HIV
}

\author{
Starry H. Rampengan \\ Bagian Ilmu Penyakit Jantung dan Pembuluh Darah \\ Fakultas Kedokteran Universitas Sam Ratulangi Manado \\ Email: starryh_rampengan@yahoo.com
}

\begin{abstract}
Heart muscle involvement associated with human immunodeficiency virus (HIV) infection may be seen as myocarditis, dilated cardiomyopathy, or as an isolated left or right ventricular dysfunction. Histopathological and ultra structural findings with different degrees of cardiac-chamber dilation have been described, and important roles of cytokines (tumor necrosis factor-alpha, interleukin-1, and interleukin-6) have been suggested. HIV infection is an important cause of dilated cardiomyopathy, with a prevalence of $3.6 \%$ among cardiomyopathy patients that live longer. HIV patients with dilated cardiomyopathy have a much worse prognosis than those with idiopathic dilated cardiomyopathy (hazard ratio of death 4.0). HIV related myocardial dysfunction may easily be overlooked due to attributing symptoms such as breathlessness, fatigue, respiratory diseases, or anaemia. The diagnosis is readily made by echocardiography which can show dilatation or impaired contractility, or both of either or both ventricles. Isolated right ventricular dysfunction can be caused by cardiomyopathy, pulmonary hypertension secondary to repeated respiratory infections, thromboembolic diseases, or recurrent pulmonary emboli from intravenous debris acquired through drug abuse. Endomyocardial biopsy in patients with heart failures associated with HIV infection has been performed in several centers, and has identified myocarditis caused by potentially treatable infections due to organisms such as toxoplasma gondii.
\end{abstract}

Keywords: cardiomyopathy, HIV infection, myocarditis, management

\begin{abstract}
Abstrak: Keterlibatan kerusakan jantung pada pasien human immunodeficiency virus (HIV) biasanya dalam bentuk miokarditis, kardiomiopati dilatasi, ataupun disfungsi ventrikel kiri atau kanan terisolasi. Penemuan histopatologik dan ultrastruktur menunjukkan perbedaan derajat dilatasi ruang-ruang jantung dipengaruhi oleh peranan beberapa jenis sitokin (tumor necrosis factor-alpha, interleukin-1 dan interleukin-6). Infeksi HIV merupakan penyebab utama terjadinya kardiomiopati dilatasi dengan prevalensi 3,6\% dari antara penderita kardiomiopati yang hidup lama. Infeksi HIV dan kardiomiopati dilatasi memiliki prognosis yang jauh lebih buruk dibandingkan dengan penderita kardiomiopati dilatasi yang idiopatik. Disfungsi miokard dalam kaitannya dengan HIV lebih mudah diidentifikasi karena adanya gejala yang jelas seperti sesak napas, mudah capek, penyakit saluran napas ataupun anemia. Hal tersebut diatas menyingkirkan kemungkinan akibat terapi paliatif dari pasien HIV. Diagnosis pasti dilakukan dengan pemeriksaan ekokardiografi, dimana terlihat dilatasi ataupun perburukan kontraktilitas jantung maupun akibat dari keduanya, atau terjadi pada kedua ventrikel. Disfungsi ventrikel kanan terisolasi dapat diakibatkan karena kardiomiopati, juga hipertensi pulmonal sekunder oleh karena infeksi saluran napas berulang, penyakit tromboemboli maupun emboli paru berulang dari debris intravena pada pecandu narkoba. Di beberapa pusat jantung telah dilakukan biopsi endomiokard pada pasien gagal jantung dengan infeksi HIV, dan diidentifikasi penyebab tersering yang dapat diobati adalah miokarditis dengan organisme seperti toxoplasma gondii.
\end{abstract}

Kata kunci: kardiomiopati, infeksi HIV, miokarditis, tatalaksana 
Data dari World Health Organization (WHO) 2007 menunjukkan bahwa sekitar 33,2 juta orang terinfeksi oleh human immunodeciency virus (HIV), 2,5 juta orang mendapat infeksi baru per tahun dan 2,1 juta orang meninggal karena acquired immunodeficiency syndromes (AIDS) per tahun. Sebagian besar pengidap HIV (68\% dari total secara global) berada di Afrika regio subSahara. ${ }^{1}$

Pertambahan jumlah penyandang HIV/ AIDS di Asia terjadi paling cepat di Indonesia. Prevalensi HIV/AIDS di Indonesia pada tahun 2005 mencapai 2\%, dan mengalami peningkatan menjadi $3 \%$ pada tahun 2007. ${ }^{2-4}$ Pada data Departemen Kesehatan Republik Indonesia Juli 1987 sampai Maret 2008 tercatat 6130 kasus infeksi HIV dan 11.868 kasus AIDS. Jakarta merupakan provinsi dengan jumlah penyandang HIV/ AIDS terbanyak di seluruh Indonesia yaitu 3077 (17\%). Sekitar 58\% pengidap HIV/ AIDS di Indonesia berusia 15-29 tahun yang merupakan usia produktif. $^{3}$

Terdapat banyak komplikasi yang bisa terjadi pada pasien dengan infeksi HIV dalam perjalanan penyakitnya. Beberapa akan mengalami fase bebas gejala yang serius sampai mereka mencapai tahap akhir dari keadaan imunosupresi; sedangkan yang lainnya akan sering mengalami komplikasi yang tidak mengancam hidup sepanjang hidupnya. Kematian biasanya terjadi karena banyak sebab termasuk infeksi sistemik, keganasan, penyakit neurologis, wasting dan malnutrisi dan kegagalan multiorgan. Kondisi yang sering terjadi dan membutuhkan terapi agresif pada pasien AIDS menjelang kematiannya adalah retinitis cytomegalovirus, candidiasis, infeksi herpes simplex virus, kompleks mycobacterium avis, kompleks demensia AIDS, infeksi hepatitis B atau C, Kaposi Sarkoma, dan pneumocystis carinii pneumonia. ${ }^{5}$

Lima penyebab utama kematian pengidap HIV, terbanyak adalah sepsis $(11,9 \%)$, penyakit ginjal $(8,8 \%)$, penyakit hati $(6,5 \%)$, hepatitis viral $(3,1 \%)$ dan perdarahan gastrointestinal $(1,8 \%)$. Salah satu penelitian membandingkan tren mortalitas HIV sebe- lum dan sesudah terapi highly active antiretroviral therapy (HAART). Antara tahun 2000-2003 kematian karena penyakit hati, hipertensi dan alkohol meningkat. Kematian karena penyakit infeksi yang berkaitan dengan AIDS seperti pneumocystosis, non tuberculosis mycobacterial, dan cytomegalovirus menurun secara bermakna. Mortalitas karena beberapa penyakit tidak mengalami perubahan seperti pneumonia, kanker, limfoma non-Hodgkin. Mortalitas karena gagal jantung kongestif termasuk yang tetap (sebelum HAART mortalitas $0,9 \%$, setelah HAART mortalitas $1,1 \%){ }^{6}$

Kelainan jantung terjadi pada semua stadium infeksi HIV. Umumnya hal tersebut tidak nyata, namun pada beberapa kasus dapat menjadi penyebab kematian. Morbiditas akibat penyakit jantung diperkirakan berkisar 6-7\% di Amerika Serikat dan Eropa, sedangkan mortalitas berkisar $1-6 \%{ }^{7} \mathrm{Ke}-$ nyataannya jumlah kelainan jantung diperkirakan lebih besar lagi karena dari penelitian otopsi prevalensi kelainan miokardium ditemukan berkisar $25-75 \% .^{8}$ Dari penelitian otopsi komplikasi kardiovaskular yang paling sering ditemukan pada pengidap HIV adalah efusi perikardium, miokarditis interstisial limfositik, kardiomiopati dilatasi (seringkali ditemukan bersamaan dengan miokarditis), endokarditis infektif, dan keganasan. ${ }^{9,10}$

Salah satu penyebab utama penyakit jantung didapat, khususnya gagal jantung adalah infeksi HIV. Kisaran insidens gagal jantung simtomatik pada penderita HIV adalah 4-28\% dengan prevalensi 4-5 juta kasus di dunia. ${ }^{9}$ Kardiomiopati dilatasi merupakan salah satu penyebab terjadinya gagal jantung pada pengidap HIV. Insidens pada pengidap asimtomatik yang menjadi kardiomiopati dilatasi adalah 15,9 kasus per 1000 orang per tahun di negara maju. Prevalensi kardiomiopati dilaporkan berkisar 9$57 \%$ di Afrika. ${ }^{8}$ Walaupun terapi kardiomiopati pada HIV secara umum sama dengan terapi pada pasien gagal jantung lainnya, tetapi prognosisnya jauh lebih buruk dibandingkan dengan kardiomiopati dilatasi yang idiopatik. $^{7}$ 
GAGAL JANTUNG SEBAGAI MANIFESTASI KARDIOMIOPATI DILATASI

Gagal jantung adalah suatu sindrom klinis kompleks yang terjadi sekunder akibat abnormalitas struktur dan atau fungsi jantung secara diturunkan atau didapat. ${ }^{11,12}$ Manifestasi kardinal gagal jantung adalah fatigue (kelelahan) dan sesak napas. Namun penelitian epidemiologis juga menemukan bahwa orang yang mempunyai abnormalitas kontraktilitas dan relaksasi yang nyata bisa saja tidak menunjukkan gejala. Keadaan ini disebut sebagai gagal jantung asimtomatik. $^{11,12}$

Terdapat beberapa terminologi deskriptif yang digunakan di kepustakaan untuk gagal jantung, diantaranya gagal jantung kongestif, sistolik atau diastolik, backward atau forward, ventrikel kiri atau kanan. Terminologi ini secara klinis tidak praktis sehingga yang paling sering dipakai adalah gagal jantung kronik atau akut. ${ }^{11,13}$

Definisi gagal jantung kronik yang paling sering dipakai adalah keadaan abnormalitas fungsi jantung yang menyebabkan kegagalan jantung memompakan darah untuk memenuhi kebutuhan metabolik jaringan tubuh. $^{13}$ Istilah gagal jantung akut didefinisikan sebagai munculnya gejala dan tanda gagal jantung yang cepat karena abnormalitas jantung. Gagal jantung akut ini dapat saja baru dideteksi (de novo) pada seseorang tanpa diketahui adanya penyakit jantung sebelumnya. Pasien yang sudah terdiagnosis gagal jantung kronik kejadian akut ini dinamakan acute on chronic atau acute decompensated heart failure. ${ }^{14,15}$

Gagal jantung bukanlah diagnosis akhir namun etiologi dan faktor pencetus harus dicari untuk tatalaksana yang tepat. Penyebab gagal jantung yang paling sering adalah kardiomiopati dilatasi sekunder atau primer. ${ }^{16}$

\section{DEFINISI DAN KLASIFIKASI KAR- DIOMIOPATI}

Kardiomiopati adalah penyakit otot jantung karena kelainan genetik, lesi miosit, atau infiltrasi jaringan miokardium. Kardiomiopati secara tradisional diklasifikasikan berdasarkan kelainan struktur dan fenotip yaitu kardiomiopati dilatasi, hipertrofik, restriktif, dan displasia ventrikel kanan aritmogenik. $^{16,17}$

Menurut WHO, kardiomiopati dilatasi dapat dibagi atas dua bentuk, yaitu kardiomiopati dilatasi primer dan sekunder. Kardiomiopati dilatasi primer digunakan untuk kelainan primer pada miokardium, tidak melibatkan kelainan struktur katup, pembuluh darah koroner, atau perikardium, bersifat familial atau genetik dan tidak diketahui dengan pasti etiologinya (idiopatik). Kardiomiopati dilatasi sekunder berarti penyebab kardiomiopati sudah diketahui seperti iskemia, kelainan katup, atau inflamasi. Kardiomiopati sekunder ini disebut juga kardiomiopati spesifik; sebagai contoh kardiomiopati iskemik, kardiomiopati valvular, atau peripartum. ${ }^{16,17}$

Petanda kardiomiopati dilatasi adalah pembesaran salah satu atau kedua ventrikel dan terdapat penurunan fungsi sistolik. Kardiomiopati ini dapat disebabkan oleh genetik-familial, virus, gangguan imunitas dan asupan alkohol. Pada 50\% kasus dengan kardiomiopati dilatasi penyebab pastinya tidak dapat ditentukan, dan dapat disebut idiopatik. $^{16,17}$

\section{PATOGENESIS KARDIOMIOPATI}

Penyebab kardiomiopati dilatasi pada penderita HIV masih belum pasti. Beberapa hipotesis patogenesis telah dipostulasikan, diantaranya miokarditis (akibat infeksi langsung HIV, infeksi oportunistik atau infeksi virus), respons autoimun terhadap infeksi virus, kerusakan mitokondria akibat obat dan defisiensi nutrisi. ${ }^{9,18}$

Miokarditis merupakan penyebab kardiomiopati dilatasi HIV yang paling banyak diteliti. Secara umum miokarditis ialah inflamasi dari otot jantung. Menurut kriteria Dallas 1987, miokarditis adalah infiltrat inflamasi miokardium dengan nekrosis atau degenerasi miosit. Penyebab paling sering adalah virus, parasit atau kondisi autoimun. Insidens viral saat ini meningkat kemungkinan disebabkan pemeriksaan molekuler yang berkembang 
pesat. $^{19}$

Patogenesis miokarditis ialah kerusakan miokardium yang diikuti oleh respons inflamasi oleh pejamu. Bila respons imun pejamu berlebihan atau tidak semestinya, proses inflamasi akan merusak jaringan jantung secara akut, menetap, menyebabkan remodelling dan selanjutnya kardiomiopati dilatasi, gagal jantung, yang berakhir dengan kematian (Gambar 1). ${ }^{17,19}$

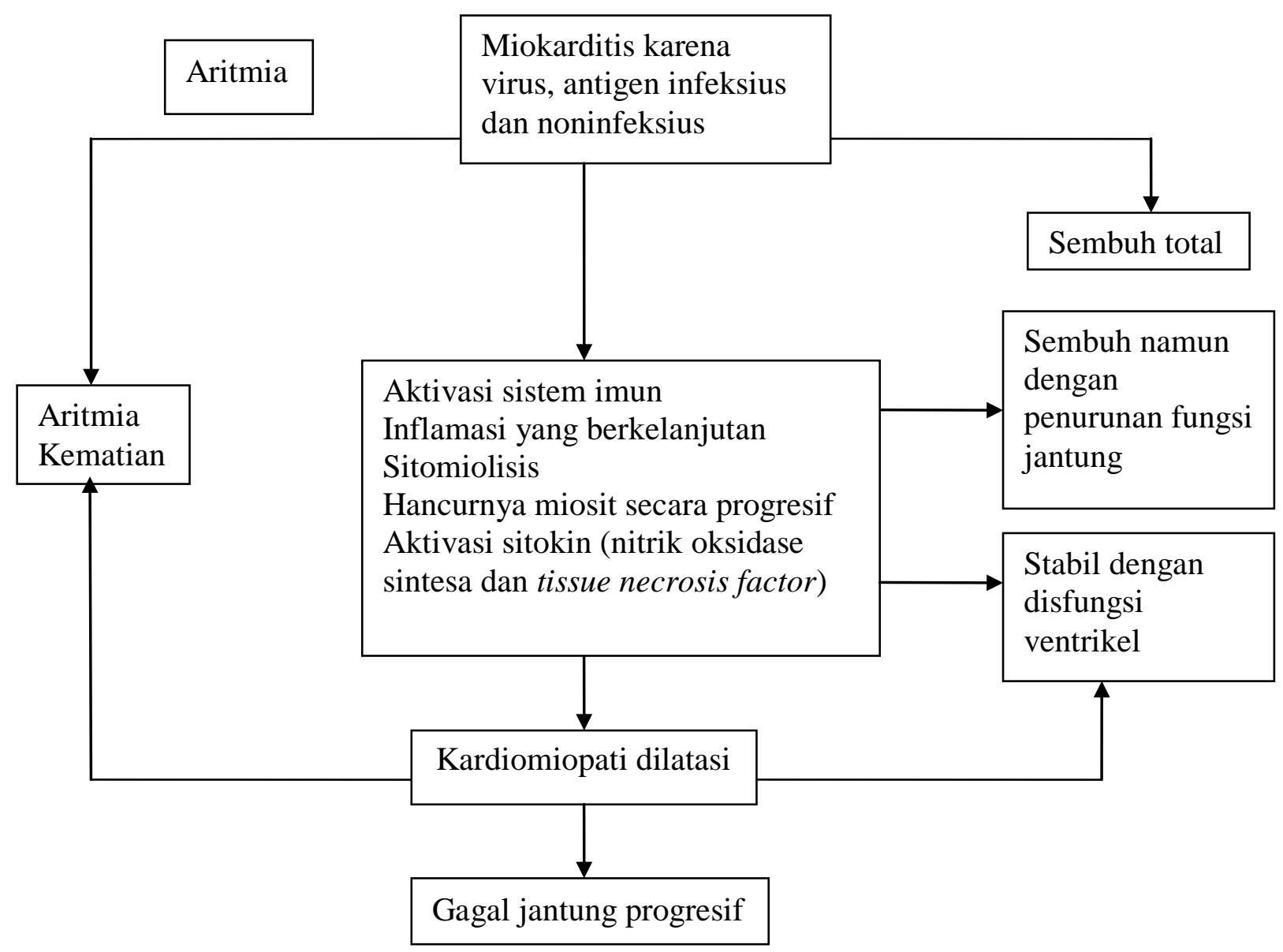

Gambar 1. Perkembangan miokarditis menjadi kardiomiopati dilatasi. Sumber: Oakley, $1997 .{ }^{20}$

Mayoritas pasien dengan miokarditis akan sembuh tanpa kecacatan, namun pada sepertiganya akan mengalami disfungsi ventrikel. $^{19,21}$ Sekitar $25 \%$ kelompok ini mengalami perburukan sehingga membutuhkan transplantasi atau meninggal. Hasil analisis histologik kasus post-mortem penderita HIV menunjukkan 14 dari 21 pasien memenuhi kriteria miokarditis, dan temuan ini meningkat menjadi $83 \%$ pada penelitian lain dengan populasi risiko tinggi. ${ }^{19}$

Kardiomiopati dilatasi dapat disebabkan oleh kerusakan langsung HIV terhadap jaringan miokardium atau enzim proteolitik, atau sitokin yang diinduksi oleh HIV atau bersamaan dengan virus lain. Toxoplasma gondii, Coxsackie virus group $\mathrm{B}$, virus Eipstein Barr, cytomegalovirus, adenovirus, dan HIV dalam miosit pernah ditemukan dalam spesimen biopsi. ${ }^{7,9,18}$ Pengidap AIDS sering terpajan dengan infeksi virus, bakteri, jamur, atau protozoa, namun sekitar $40 \%$ tidak mengalami infeksi oportunistik sebelum ditemukannya gejala jantung. ${ }^{9}$

Pada pemeriksaan otopsi dan biopsi hanya sedikit ditemukan infiltrasi sel-sel inflamasi dalam miosit jantung. Hal ini disebabkan karena miosit jantung tidak mempunyai 
reseptor CD4+. HIV dapat menginfeksi sel interstisial miokardium, namun tidak pada miosit. ${ }^{7,9}$ Peningkatan jumlah sel-sel interstisial yang terinfeksi telah ditemukan pada pasien dengan miokarditis. Enzim-enzim proteolitik atau tumor necrosis factor- $\alpha$ (TNF- $\alpha$ ) atau interleukin yang mengikuti akan menimbulkan kerusakan miosit. ${ }^{9}$

Infeksi HIV meningkatkan produksi TNF- $\alpha$ yang mengubah homeostasis kalsium dan meningkatkan produksi nitrik oksida, transforming growth factor-beta (TGF- $\beta$ ), dan endothelin-1. Peningkatan jumlah nitrik oksida mengakibatkan efek inotropik negatif dan bersifat sitotoksik terhadap miosit. Kadar TNF- $\alpha$ dan sintesis nitrik oksida di miosit lebih tinggi pada pasien kardiomiopati dilatasi dengan HIV dibanding dengan yang tanpa HIV. ${ }^{9,18}$

Beberapa penelitian melaporkan bahwa pasien dengan ensefalopati berisiko lebih tinggi untuk meninggal karena gagal jantung kongestif dibanding dengan yang tanpa ensefalopati. Sel-sel reservoir di miokardium dan korteks serebral dapat saja masih mengandung HIV di permukaannya untuk jangka waktu tertentu, dan secara kronik melepaskan sitokin sitotoksik dan menyebabkan kerusakan jaringan yang progresif walaupun sudah diberi terapi antiretroviral. $^{22}$

Zidovudine atau azidothymidine (AZT), salah satu obat antiretroviral untuk pengobatan HIV dikatakan mempunyai efek samping miopati otot rangka. Kultur miosit jantung pasien HIV yang diobati dengan AZT menunjukkan abnormalitas mitokondria. Namun miopati otot jantung karena obat ini belum terbukti secara klinis. Jarang sekali terjadi perbaikan fungsi ventrikel kiri dengan penghentian obat. Pugliese et $\mathrm{al}^{23}$ melaporkan prevalensi kardiomiopati menurun secara bermakna setelah terapi (HAART).

Nutrisi yang buruk pada pasien HIV sering terjadi terutama pada fase lanjut. Defisiensi salah satu mikronutrien yang sering dilaporkan pada pasien HIV adalah defisiensi selenium., ${ }^{9,24}$ Kekurangan selenium meningkatkan virulensi Coxsackie virus terhadap jaringan jantung. Pemberian seleni- um dapat memulihkan kardiomiopati dan fungsi ventrikel kiri. Defisiensi mikronutrien lainnya yang dihubungkan dengan disfungsi ventrikel kiri adalah defisiensi vitamin B12, karnitin, serta hormon tiroid dan pertumbuhan. Pada pasien HIV kadar elemen-elemen ini dapat berubah. ${ }^{9}$

\section{DETEKSI GANGGUAN KARDIOVAS- KULAR PADA PASIEN HIV}

Dokumentasi riwayat dan pemeriksaan fisik yang cermat untuk penyakit kardiovaskular adalah sangat penting untuk tatalaksana pasien dengan HIV. Gejala gagal jantung sering bercampur juga dengan kondisi yang lain seperti infeksi paru, hipertensi pulmonal, anemia, hipertensi portal, malnutrisi, dan keganasan. Pasien dengan penurunan fungsi ventrikel kiri dapat saja tidak mempunyai gejala klinis atau mengalami gagal jantung kelas III atau IV menurut klasifikasi New York Heart Association (NYHA). ${ }^{9}$

Hasil pemeriksaan EKG menunjukkan kerusakan konduksi yang nonspesifik atau perubahan repolarisasi. Pemeriksaan radiografik mempunyai sensitivitas dan spesifitas yang rendah untuk pasien HIV dengan gagal jantung kongestif. ${ }^{9}$ Pemeriksaan Brain Natriuretic Peptida (BNP) pada populasi dengan dan tanpa infeksi HIV menunjukkan bahwa kadar BNP ini berkorelasi terbalik dengan fungsi ventrikel kiri. Pemeriksaan ini dapat membantu penegakan diagnosis gagal jantung pasien pengidap HIV. ${ }^{9}$

Pemeriksaan ekokardiografi direkomendasikan untuk pasien HIV dengan faktor risiko kardiovaskular yang meningkat, dengan manifestasi penyakit kardiovaskular, atau dengan gejala paru yang menetap atau tidak dapat dijelaskan. Pemeriksaan ini sebaiknya dilakukan saat infeksi HIV ditegakkan, lalu diulang setiap 1-2 tahun kemudian atau sesuai dengan klinis. ${ }^{9}$

\section{TATALAKSANA KARDIOMIOPATI PADA PASIEN DENGAN HIV}

Secara umum, terapi kardiomiopati pada pasien dengan HIV sama dengan terapi 
pada pasien gagal jantung lainnya yaitu: diuretik, digoksin, penghambat beta, antagonis aldosteron dan $A C E$ inhibitors. Infeksi lainnya atau oportunistik harus dicari dan diterapi untuk memperbaiki keadaan kardiomiopati. ${ }^{9,18}$

Pemeriksaan ekokardiografi sebaiknya dilakukan setiap interval empat bulan setelah terapi dimulai. Apabila fungsi jantung memburuk, biopsi sebaiknya dipertimbangkan. Pasien dengan gagal jantung kongestif yang tidak menunjukkan perbaikan setelah terapi selama dua minggu mungkin akan mendapat manfaat dengan kateterisasi dan biopsi endomiokardium. Biopsi bisa menunjukkan infiltrat limfositik yang merupakan tanda miokarditis atau infeksi oportunistik. Selain itu jaringan perlu dievaluasi untuk kelainan mitokondria yang bisa terjadi karena obat. Angiografi diperlukan bila terdapat kecurigaan penyakit aterosklerosis atau adanya gejala klinis. ${ }^{9}$ Telah diketahui bahwa kadar troponin T meningkat pada keadaan miokarditis. Oleh karena itu pemeriksaan troponin $\mathrm{T}$ diindikasikan bila terdapat disfungsi ventrikel kiri. Bila miokarditis memang telah terjadi, maka pemberian imunoglobulin perlu dilakukan., ${ }^{9,19}$

Imunoglobulin intravena telah berhasil mengobati kardiomiopati akut dan miokarditis non spesifik yang tidak terinfeksi HIV. Terapi imunoglobulin bermanfaat pada penyakit Kawasaki, yaitu suatu penyakit imunologik yang menyerupai infeksi HIV. Infus imunoglobulin pada anak yang terinfeksi HIV mengurangi disfungsi ventrikel kiri, meningkatkan ketebalan dinding miokardium, dan mengurangi ketegangan dinding ventrikel kiri. Manfaat terapi imunoglobulin ini mungkin merupakan hasil bersihan autoantibodi dan pengurangan sekresi atau efek sitokin maupun faktor pertumbuhan seluler. Terapi imunomodulator mungkin berguna pada pasien anak dengan fungsi ventrikel yang menurun. ${ }^{9}$

Selain hal-hal di atas status nutrisi pasien harus dievaluasi. Pasien dengan defisiensi nutrien tertentu harus menerima suplemen. Suplemen selenium, karnitin, multivitamin atau ketiganya mungkin berguna terutama pada pasien dengan anoreksia, wasting, atau diare. ${ }^{9}$ Transplantasi jantung merupakan pilihan pengobatan untuk pasien gagal jantung stadium akhir. Hal ini pernah dilaporkan pada pasien dengan HIV, namun terapi ini belum secara luas diterima dan masih sulit diaplikasikan. ${ }^{9}$

\section{PROGNOSIS}

Prognosis pasien dengan kardiomiopati dilatasi bervariasi karena etiologi yang mendasari berbeda dan sangat mempengaruhi perjalanan penyakitnya. Beberapa kardiomiopati mempunyai ketahanan hidup (survival) jangka panjang yang baik, sedangkan kardiomiopati karena amiloidosis dan infeksi HIV mempunyai prognosis yang paling buruk. Pasien kardiomiopati dengan HIV mempunyai prognosis yang lebih buruk dibandingkan dengan pasien kardiomiopati idiopatik (hazard ratio untuk kematian adalah 4.00). ${ }^{7,17}$ Kurva ketahanan hidup pasien dengan kardiomiopati dapat dilihat pada Gambar 2.

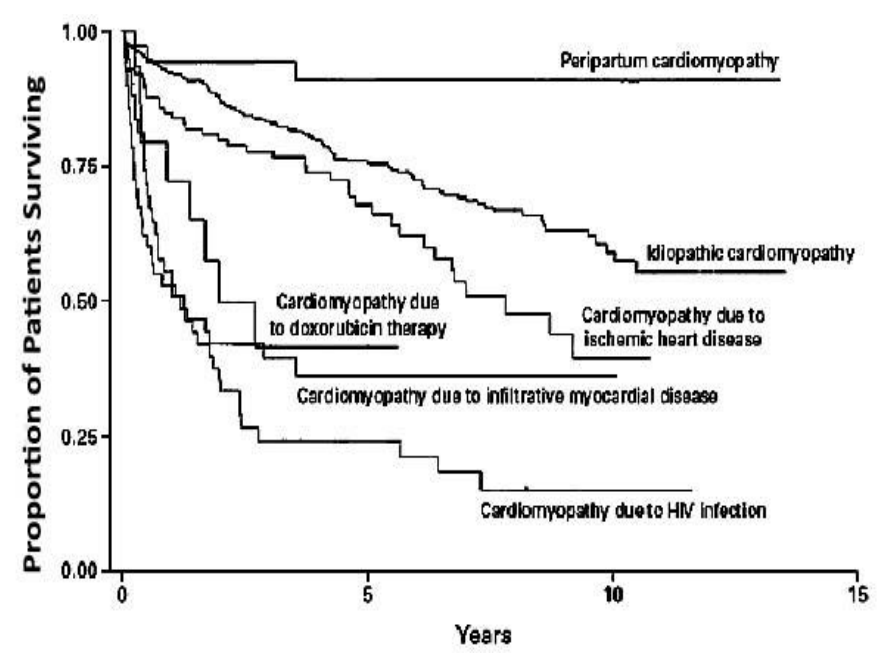

Gambar 2. Kurva ketahanan hidup sesuai dengan penyebab kardiomiopati. Sumber: Felker et al, $2000 .^{25}$

Mortalitas pasien HIV dengan kardiomiopati dilatasi yang meningkat tidak tergantung dengan jumlah CD4, usia dan jenis kelamin. Gambar 3 menunjukkan pasien dengan kardiomiopati dilatasi mempunyai prognosis yang lebih buruk diban- 
dingkan yang dengan penurunan fungsi ventrikel kiri dan kanan pada HIV dan AIDS. Median ketahanan hidup pada kematian karena AIDS adalah 472 hari untuk pasien dengan jantung yang normal, dan 101 hari pada pasien dengan disfungsi ventrikel kiri pada stadium yang sama sebelum terapi HAART. ${ }^{7}$

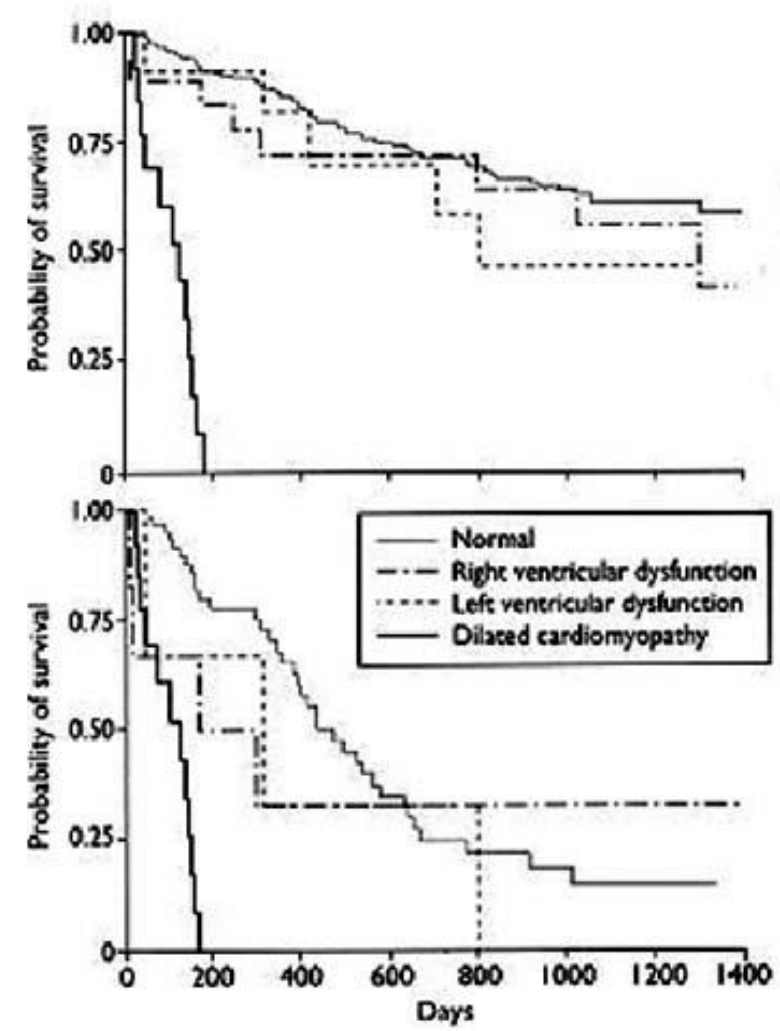

Gambar 3. Atas: kurva ketahanan hidup untuk 296 pasien HIV dengan jantung normal dan disfungsi ventrikel kanan dan kiri. Bawah: kurva ketahanan pasien AIDS dengan CD4 < 20x 106/l. Sumber: Moronia \& Antinorin, 2003. ${ }^{7}$

\section{SIMPULAN}

Kardiomiopati dilatasi termasuk salah satu komplikasi jantung yang paling sering terjadi pada pasien dengan infeksi HIV. Patogenesisnya meliputi miokarditis (akibat infeksi langsung HIV, infeksi oportunistik atau infeksi virus), respons autoimun terhadap infeksi virus, kerusakan mitokondria akibat obat dan defisiensi nutrisi. Deteksi kardiomiopati dilatasi dilakukan dengan cara anamnesis riwayat dan pemeriksaan fisik yang cermat, EKG, pemeriksaan radiografik dan ekokardiografi. Tatalaksananya adalah terapi gagal jantung, mengatasi infeksi lain, memperbaiki nutrisi, dan bila terjadi perburukan dapat dilakukan kateterisasi dan biopsi. Prognosis kardiomiopati dilatasi pada infeksi HIV paling buruk dibanding dengan sebab yang lain.

\section{DAFTAR PUSTAKA}

1. UNAIDS, WHO. Aids epidemic update: UNAIDS Publications 2007. [homepage on the internet] 2007. Nodate [cited 2011 Aug 03. Available from: http:// www.unsaids.org/pub/EPIslides/2007/20 07_epiudpdate_en.pdf.

2. AIDS KP. The point: Indonesia's Hiv prevalence is highest in Asia: WHO. 2008. [homepage on the internet] 2008. Nodate [cited 2011 Aug 01]. Available from: http//www.aidsindonesia.or.id.

3. Statistik kasus hiv/aids di Indonesia 2008 Ditjen PPM data dan PL Depkes RI. [homepage on the internet] 2008. Nodate [cited 2011 Aug 02]. Available from: http://www.spiritia.or.id/stats/statscurr.p df.

4. UNAIDS, WHO. Hiv/aids in the south-east Asia region 2007. [homepage on the internet 2008. Nodate [cited 2011 Aug 05]. Available from: http//www.searo. who. int/linkfiles/AIDS_SEARO_report07.pdf.

5. Wood CG, Whittet S, Bradbeer CS. ABC of palliative: HIV infection and AIDS. BMJ. 1997;315: 1433-36.

6. Hooshyar D, Hanson DL, Wolfe M, Selik RM, Buskin S, McNaghten AD. Trends in perimortal conditions and mortality rates among HIV-infected patients. AIDS. 2007;21:2093-100.

7. Moronia M, Antinorin S. HIV and direct damage of organs: disease spectrum before and during the highly active antiretroviral therapy era. AIDS. 2003; 17:51-64.

8. Ntsekhe M, Hakim J. Impact of human immunodeficiency virus infection on cardiovascular disease. Circulation. 2005;112:3602-07.

9. Fisher SD, Lipshultz. Cardiovascular abnormalities in HIV-infected individuals. In: Braunwald E, Libby P, Bonow RO, Mann DL, Zipes DP, editors. 
Braunwald's Heart Disease A Textbook of Cardiovascular Medicine (Eight Edition). Massachuset: Elsevier, 2007; p.1793-803.

10. Restrepo CS, Diethelm L, Lemos JA, Velasquez E, Ovella T, Martinez S, Carillo J, Lemos DF. Cardiovascular complications of human immunodeficiency virus infection. RadioGraphics. 2006;26:213-31.

11. Hess O, Carroll J. Clinical assesment of heart failure. In: Braunwald E, Libby P, Bonow RO, Mann DL, Zipes DP, editors. Braunwald's Heart Disease A Textbook of Cardiovascular Medicine (Eight Edition). Massachuset: Elsevier, 2007; p.561-2.

12. American College of Cardiology/American Heart Association Guideline Updates for Diagnosis and Management of Chronic Heart Failure in Adult. American College of Cardiology/American Heart Association, 2005; p.158-61.

13. Task force for the diagnosis and treatment of chronic heart failure European Society of Cardiology. Guidelines for the diagnosis and treatment of chronic heart failure, 2001;p.2-3.

14. Task force for the diagnosis and treatment of acute heart failure European Society of Cardiology. Guidelines for the diagnosis and treatment of acute heart failure;2005.p 4-5.

15. Teerlink JR. Diagnosis and management of acute heart failure. In: Braunwald $\mathrm{E}$, Libby P, Bonow RO, Mann DL, Zipes DP, editors. Braunwald's Heart Disease A Textbook of Cardiovascular Medicine (Eight Edition). Massachuset: Elsevier, 2007; p.583-5.

16. Bristow MR, Mestroni L, Bohlmeyer T, Gilbert E. Dilated cardiomyopathies. In: Fuster V, Alexander RW, O'Rourke RA, Roberts R, King SP, Wellens H, editors. Hurst's The Heart (Tenth Edition). New York: McGrawHill, 2001; p.1947-61.

17. Hare JM. The dilated, restrictive, and infiltrative cardiomyopathies. In: Braunwald E, Libby P, Bonow RO, Mann DL, Zipes DP, editors. Braunwald's Heart Disease A Textbook of Cardiovascular Medicine (Eight Edition). Massachuset: Elsevier, 2007; p.1731-47.

18. Cheitlin MD. AIDS and the cardiovascular system. In: Fuster V, Alexander RW, O'Rourke RA, Roberts R, King SP, Wellens H, editors. Hurst's The Heart (Tenth Edition). New York: McGrawHill, 2001; p.2033-40.

19. Liu PP, Schultheiss HP. Myocarditis in HIV-infected individuals. In: Braunwald E, Libby P, Bonow RO, Mann DL, Zipes DP, editors. Braunwald's Heart Disease A Textbook of Cardiovascular Medicine (Eight Edition). Massachuset: Elsevier, 2007; p.1775-88.

20. Oakley C. Aetiology, diagnosis, investigation, and management of the cardiomyopathies. BMJ. 1997;315:1520-4.

21. Mancini M, Beniarminovitz A. Myocarditis and specific cardiomyopathies. In: Fuster V, Alexander RW, O'Rourke RA, Roberts R, King SP, Wellens H,editors. Hurst's The Heart (Tenth Edition). New York: McGrawHill, 2001; p.2001-11.

22. Barbaro G. Cardiovascular manifestations of HIV. Circulation. 2002;106;1420-5.

23. Torre D, Speranza F, Martegani R. Impact of highly active antiretroviral therapy on organ-specific manifestations of HIV-1 infection. HIV Medicine. 2005; 6:66-78.

24. Enwonwu C. Complex interactions between malnutrition, infection and immunity: relevance to HIV/AIDS infection. Nigerian Journal of Clinical \& Biomedical Research. 2006;1:6-10.

25. Felker GM, Thompson R, Hare J, Hruban R, Clemetson D, Howard DL, et al. Underlying causes and long-term survival in patients with initially unexplained cardiomyopathy. NEJM. 2000; $15: 1077-84$ 